Review

\title{
Nutritional Strategies for the Preservation of Fat Free Mass at High Altitude
}

\author{
Stacie L. Wing-Gaia \\ Division of Nutrition, University of Utah, 250 South 1850 East, Salt Lake City, UT 84112, USA; \\ E-Mail: stacie.wing@health.utah.edu; Tel.: +1-801-585-9623; Fax: +1-801-585-3874
}

Received: 14 January 2014; in revised form: 22 January 2014 / Accepted: 23 January 2014 /

Published: 13 February 2014

\begin{abstract}
Exposure to extreme altitude presents many physiological challenges. In addition to impaired physical and cognitive function, energy imbalance invariably occurs resulting in weight loss and body composition changes. Weight loss, and in particular, loss of fat free mass, combined with the inherent risks associated with extreme environments presents potential performance, safety, and health risks for those working, recreating, or conducting military operations at extreme altitude. In this review, contributors to muscle wasting at altitude are highlighted with special emphasis on protein turnover. The article will conclude with nutritional strategies that may potentially attenuate loss of fat free mass during high altitude exposure.
\end{abstract}

Keywords: hypoxia; mountaineering; body composition; muscle wasting; protein synthesis; leucine

\section{Introduction}

It is well-documented that weight maintenance above $5000 \mathrm{~m}$ is extremely difficult, if not impossible, in free living adults. A number of explanations have been proposed including anorexia, elevated basal metabolic rate, body water loss, and altered satiety hormones. However, the majority of studies support that altitude-induced weight loss is largely a function of negative energy balance secondary to inadequate energy intake [1-9]. Energy expenditure is elevated at altitude and is equivalent to moderate to high intensity exercise conducted at sea level [3]. When this energy expenditure is combined with suboptimal energy intakes of $50 \%-70 \%$ of daily requirements weight loss occurs [1-9]. 
Of particular concern is the composition of weight loss. Above $5000 \mathrm{~m}$ fat free mass (FFM) accounts for as much as $60 \%-70 \%$ of weight loss $[1,8,9]$. Less clear is why FFM comprises such a large percentage of weight loss. Decreased physical inactivity, sleep cycle disruption, cold exposure, and hypoxia and nutrition-related changes in protein metabolism may all play a role in muscle wasting associated with high altitude. Fat free mass is an important participant in the regulation of metabolism, serving as a reservoir of glucogenic amino acids and nitrogen. Loss of FFM compromises aerobic capacity [10], muscle strength [11], physical performance [12], and immune function [13] at high altitude increasing the risk of illness and injury in extreme environments.

Currently, there is limited research on the mechanisms of muscle wasting at altitude. In this review potential contributors to muscle wasting at altitude are discussed with a special emphasis on the independent effects of hypoxia and concurrent altitude-related nutritional issues (i.e., caloric restriction and low protein intake) on protein turnover as influenced by protein synthesis and protein degradation. Nutritional strategies that may potentially attenuate loss of FFM during high altitude exposure are reviewed.

\section{Weight Loss and Body Composition Changes with Altitude Exposure}

Weight loss appears to be an unavoidable consequence of sustained hypobaric hypoxia in both laboratory and field environments [1-9]. Several studies have reported body weight losses of $5 \%-15 \%[1,5,7,8,14]$ with losses primarily a function of both the duration of hypoxic exposure and altitude obtained [15,16]. Weight loss can be reduced but not completely abated below $5000 \mathrm{~m}$ with carefully prescribed dietary intake and physical activity [17-19], but above $5000 \mathrm{~m}$ weight maintenance becomes a significant challenge $[1,3,4,14]$. Although normobaric hypoxia most likely induces weight loss as well, there is scant research comparing normobaric hypoxia and hyopobaric hypoxia on anorexia or specifically energy metabolism. There are some differing influences upon certain respiratory and cardiac functions [20], postural stability [21], oxidative stress [22], and acute mountain sickness (AMS) [23], but in the final analysis, it is the degree of oxygen saturation of hemoglobin and myoglobin that seems to exert the most significant effect upon metabolic processes [20,24].

The reasons for altitude-induced weight loss are multifactorial. At high altitude, appetite and consequently energy intake is greatly reduced. The majority of studies report a $30 \%-50 \%$ decrease in energy intake during high altitude sojourns $[1-3,5,6,8,9,14]$. Following acclimatization at $4300 \mathrm{~m}$ appetite generally improves, but most studies support that appetite continues to decrease above $5000 \mathrm{~m}$ [15]. Altitude-associated anorexia has been correlated with acute mountain sickness (AMS), a high altitude illness characterized by headache, dyspnea, nausea, vomiting, anorexia, fatigue, and insomnia [25]. However, anorexia may also occur independent of AMS [14]. Satiety hormones are also influenced by hypoxia. Leptin, a key neuroendocrine appetite suppressant, significantly increased following a $17 \mathrm{~h}$ overnight normobaric hypoxic exposure simulating $4100 \mathrm{~m}$ [26]. Conversely, under hypobaric hypoxic conditions $(4300 \mathrm{~m})$, leptin did not change from sea level in either calorically restricted or adequately fed individuals [27]. Further research is warranted to examine the role of the neuroendocrine system in appetite regulation at altitude.

In addition to suboptimal energy intakes, energy expenditure is increased with altitude exposure. This increase is largely attributed to a substantial but transient increase in basal metabolic rate 
(BMR) [17,24]. Doubly labeled water experiments on Mt. Everest climbers indicate physical activity energy expenditure values of 1.85-3.0 times sea level resting energy expenditure (REE) [2,3,5,17]. To put this in perspective, an REE multiple of 1.5 is equivalent to low/sedentary activity and a REE multiple of five equivalent to participating in the Tour De France [28]. The above values reflect activity typical of moderate activity [3]. In summary, weight loss appears to be more closely related to inadequate energy intake than extreme energy expenditure. The result is a loss of fat mass but also the undesired loss of FFM [5] (Table 1).

\section{Body Composition Changes}

Caloric restriction induces weight loss which is generally a mix of water, fat and FFM. With caloric restriction under normoxic conditions (i.e., sea level), FFM comprises approximately 25\% of body weight loss [29]. This can be mitigated through diet (i.e., increased protein) [30-33] and exercise [29]. However, with caloric restriction under hypoxic conditions (i.e., high altitude) FFM comprises as much as $60 \%-70 \%$ of weight loss [1,9,34]. In subjects exposed to 40 days of hypobaric hypoxia equivalent to $8848 \mathrm{~m}$, FFM comprised $67 \%$ of body weight loss with a corresponding $17 \%$ reduction in thigh cross-sectional area [1]. In field conditions, Hoppler et al. [10] found a similar $20 \%$ reduction in the vastus lateralis cross-sectional area in 14 mountaineers following eight weeks above $5000 \mathrm{~m}$. Further, on an ascent of Mt. Shishapangma (8046 m), subjects lost $1.9 \mathrm{~kg}$ FFM compared to $0.9 \mathrm{~kg}$ fat mass [9]. Reynolds et al. [5] also reported a reduction in absolute (kg), but not relative (\%), FFM in subjects climbing Mt. Everest.

There are some studies that support a greater loss of fat mass (FM) than FFM at high altitude. However, differences may be due to altitude attained and limitations of measurement techniques. Fulco et al. [35] compared whole body bioelectrical impedance analysis (BIA) and 6-site skinfold measurements to densitometry (hydrostatic weighing) and found that both BIA and skinfolds overestimated FFM loss compared to densitometry. Tanner et al. [7] compared three measures of body composition in five climbers on Mt. McKinley, Alaska with similar results. Fat free mass was found to be the predominant portion of weight loss for both 12-site skinfolds and magnetic resonance imaging (75\% and 62\%, respectively), but not densitometry (77\% FM; 23\% FFM). Bioelectrical impedance analysis in particular is an unreliable measure of body composition at high altitude due to fluid perturbations associated with altitude exposure [35]. Further, skinfolds require careful training and tightly controlled hydration and exercise. Measurement of skinfolds with ultrasound is a more reliable method than with calipers [36] and has been used successfully in a high altitude field study [37]. However, body weight is included in skinfold prediction equations calculating FM and FFM and body weight is influenced by body water loss. Dual Energy Xray Absorptiometry (DXA) is generally recognized as the gold standard to measuring body composition, but currently whole body portable DXA scans are not available for field applications at high altitude. Field measurements of body composition are an area of much needed research. 
Table 1. Body composition changes at altitude.

\begin{tabular}{|c|c|c|c|c|c|c|c|c|c|}
\hline Reference & $N$ & Conditions & Altitude (m) & $\begin{array}{l}\text { Days at } \\
\text { Altitude }\end{array}$ & $\begin{array}{c}\text { Total } \\
\text { Weight Loss } \\
(\mathrm{kg}) \\
\end{array}$ & $\begin{array}{c}\text { Body Composition } \\
\text { Method }\end{array}$ & $\begin{array}{l}\text { Body Fat } \\
\text { Loss (kg) }\end{array}$ & $\begin{array}{c}\text { FFM * } \\
\text { Loss (kg) }\end{array}$ & $\begin{array}{c}\text { \% Weight } \\
\text { Loss as FFM }\end{array}$ \\
\hline \multirow{2}{*}{ Boyer and Blume [38] } & \multirow{2}{*}{$14 * *$} & \multirow{2}{*}{ Field } & $<5400$ & 23 & 1.9 & \multirow{2}{*}{ Skinfolds } & 1.34 & 0.56 & 29.5 \\
\hline & & & $>5400$ & 26 & 4.0 & & 1.2 & 2.8 & 70.0 \\
\hline Rose et al. [1] & 8 males & $\begin{array}{l}\text { Hypobaric } \\
\text { chamber }\end{array}$ & Up to 8846 & 38 & 7.4 & Densitometry & 2.51 & 5.05 & 66.8 \\
\hline \multirow{3}{*}{ Fulco et al. [35] } & \multirow{3}{*}{16 males } & \multirow{3}{*}{ Field } & \multirow{3}{*}{$3700-4300$} & \multirow{3}{*}{16} & \multirow{3}{*}{5.9} & Densitometry & 3.46 & 2.44 & 41.4 \\
\hline & & & & & & Skinfolds & 2.53 & 3.37 & 57.1 \\
\hline & & & & & & Bioelectrical impedance & 1.34 & 4.56 & 77.3 \\
\hline Westerterp et al. [2] & $\begin{array}{c}3 \text { male } \\
2 \text { female }\end{array}$ & Field & $5300-8872$ & $30^{\dagger}$ & 2.2 & Skinfolds & 1.4 & 0.8 & 36.4 \\
\hline Westerterp et al. [3] & $\begin{array}{c}4 \text { male } \\
2 \text { female }\end{array}$ & Field & 6542 & 21 & 4.9 & Skinfolds & 3.5 & 1.3 & 27.0 \\
\hline Pulfrey and Jones [9] & $\begin{array}{c}5 \text { male } \\
1 \text { female }\end{array}$ & Field & $5900-8046$ & $40^{\dagger}$ & 3.7 & Skinfolds & 0.9 & 1.9 & 51.4 \\
\hline Armellini et al. [8] & \multirow[t]{2}{*}{$\begin{array}{l}10 \text { male } \\
2 \text { female }\end{array}$} & Field & $\geq 4500$ & 16 & 3.3 & Bioelectrical impedance & 2.2 & 1.1 & 33.3 \\
\hline \multirow{3}{*}{ Tanner et al. [7] } & & \multirow{3}{*}{ Field } & \multirow{3}{*}{$2200-4300$} & \multirow{3}{*}{21} & \multirow{3}{*}{4.2} & Densitometry & 3.2 & 1.0 & 23.0 \\
\hline & \multirow[t]{2}{*}{5 male } & & & & & Skinfolds & 1.1 & 3.2 & 75.0 \\
\hline & & & & & & Magnetic resonance & 1.7 & 2.5 & 62.0 \\
\hline \multirow{2}{*}{$\begin{array}{l}\text { Wing-Gaia } \\
\text { et al. }[37]^{*}\end{array}$} & 10 male & \multirow{2}{*}{ Field } & \multirow{2}{*}{$2835-5364$} & \multirow{2}{*}{13} & Control: 1.9 & \multirow{2}{*}{ Ultrasound skinfolds } & 0.6 & 1.2 & 66.0 \\
\hline & 8 female & & & & Leucine: 1.8 & & 1.1 & 0.8 & 42.0 \\
\hline
\end{tabular}

* Fat free mass; ** Gender not specified; ${ }^{\dagger}$ Study period was day 17-25 [2] and day 30-38 [9]; ${ }^{\ddagger}$ Supplemented with leucine (7 g/day) [37]. 


\section{Potential Mechanisms of Altitude-Induced Muscle Wasting}

Muscle wasting is a well-documented occurrence with chronic high altitude exposure. Skeletal muscle is of particular importance given it contains the majority of body proteins and comprises almost half of human body weight [39]. As such skeletal muscle accounts for a large proportion of whole body protein turnover. Protein turnover is a dynamic process with approximately $1 \%-2 \%$ of skeletal muscle broken down and synthesized daily under normal ambient conditions [40]. A chronic imbalance of proteins synthesized or degraded (or both) will ultimately influence the size of muscle mass. It is conceivable that altitude could exert its influence upon muscle wasting (turnover) by altering muscle protein synthesis or degradation. Control of breakdown is largely regulated through the ubiquitin proteasome (UP), lysosomal, and calpains systems [41]. Muscle contraction and branched-chain amino acids are potent stimulators of muscle protein synthesis (MPS) and are important daily anabolic stimuli necessary to maintain muscle mass. From a cellular perspective, the mammalian target of rapamycin (mTOR) pathway is a central point of control for muscle protein synthesis and occupies a central point of convergence for nutritional and contractile anabolic signals. It is therefore a useful point of reference in discussing mechanisms that may contribute to muscle loss at altitude (Figure 1).

Figure 1. A simplified schematic diagram of the mammalian target of rapamycin complex 1 (mTORC1) signaling pathway and proposed cellular regulation of muscle protein synthesis in response to hypoxia, caloric restriction, insulin, muscle contraction, and leucine. Proteins labeled as gray are positive regulators of mTORC1 and/or muscle protein synthesis and proteins labeled black are negative regulators of mTORC1 and/or muscle protein synthesis. TSC1, tuberous sclerosis complex 1; TSC2, tuberous sclerosis complex 2; Rheb, Ras-homologue enriched in brain; REDD1, gene regulated in DNA damage responses and development; AMPK $\alpha$, AMP-activated protein kinase alpha; PRAS40, proline-rich Akt substrate 40; Raptor, regulatory associated protein of mTOR; S6K1, p70 ribosomal S6 kinase 1; rpS6, ribosomal protein S6; eEF2, eukaryotic elongation factor 2; 4E-BP1, 4E binding protein 1; eIF-4F, eukaryotic initiation factor 4F; PA, phosphatidic acid; Akt, protein kinase B.

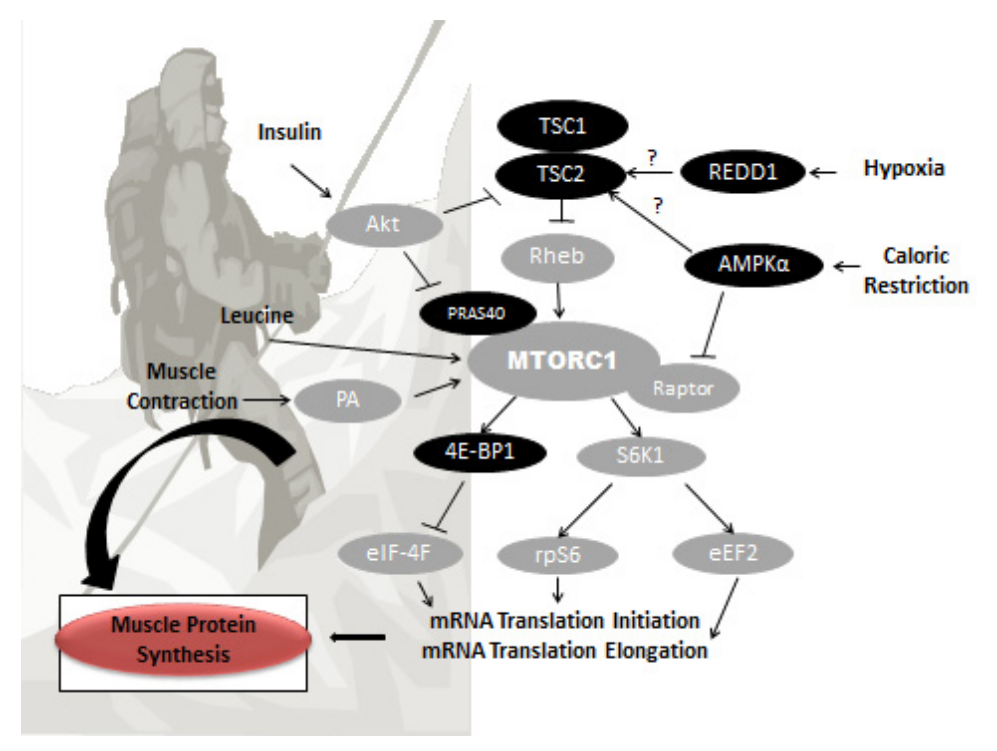




\subsection{Hypoxia}

Perhaps the largest contributor to muscle wasting at altitude is hypoxia. Evidence suggests that hypoxic exposure may impair MPS through downregulation of mTOR by the hypoxia-induced REDD1 gene [42]. Of particular importance is that this downregulation is independent of hypophagia [43] suggesting that while nutrition may be able to mitigate muscle wasting, it most likely will not completely prevent muscle wasting. Early studies in rat models noted decreased MPS following $6 \mathrm{~h}$ of hypobaric hypoxia [44] and impaired growth rate following 14 days of high altitude exposure [45]. Bigard et al. [46] also found depressed growth rate in rats exposed to hypobaric hypoxia (6000 $\mathrm{m}$ ) for 26 days despite high dietary protein intake. In humans, Vigano et al. [47] found a reduction in mTOR expression following 7-9 days of hypobaric hypoxia (4559 m). Conversely, Etheridge et al. [48] exposed seven healthy young adult men to $3.5 \mathrm{~h}$ of normobaric hypoxia and found no effect on MPS at rest. However, when these participants completed a bout of resistance exercise following hypoxic exposure, the normal contraction-induced increase in MPS was significantly blunted (1.4 vs. three-fold increase in MPS). Similarly, in a comparison of subjects who were either flown or walked to $4559 \mathrm{~m}$, those walking had a $35 \%$ increase in fractional synthetic rate compared to those not walking [49]. However, the increase in MPS following walking was much lower than comparable sea level exercise studies [50] suggesting that post-exercise MPS was blunted in some manner by acute hypoxia.

Limited research suggests that muscle proteolysis may also be affected with hypoxic exposure. Using a rat model, Chaudhary et al. [51] examined the effects of 3, 7, and 14 days of hypobaric hypoxia $(7620 \mathrm{~m})$ on protein turnover under eucaloric conditions. Following physical activity, there was a 1.5-fold increase in protein synthesis. However, there was a five-fold increase in protein degradation secondary to upregulation of the UP and calpains systems. In humans, Holm et al. [52] reported similar findings. Following 7-9 days of acclimatization at $4559 \mathrm{~m}$, whole body protein degradation was increased. In summary, limited data suggests MPS is downregulated and muscle proteolysis upregulated with hypoxia. Downregulation of MPS can partially be overcome with resistance exercise, but this may not be feasible at altitude where strenuous physical exercise is often an ongoing daily occurrence. Although it is important to note that hypoxia-induced downregulation of MPS occurs regardless of nutritional status [43,46], nutritional deficits (i.e., calories and protein) may potentiate the problem. Therefore, targeting diet and nutrient intake may be a more practical approach to influencing MPS at altitude.

\subsection{Caloric Restriction and Suboptimal Protein Intake}

As previously discussed, a primary contributor to weight loss at altitude is low energy intake. Energy status influences MPS. Thus it is likely subcaloric intake contributes to both impaired MPS and increased proteolysis at altitude. This effect is exacerbated in combination with hypoxia as demonstrated by Favier et al. [43] who exposed rats to hypobaric hypoxia for 26 days. A $210 \%$ increase in REDD1 protein level was noted in hypophagic rats compared to pair-fed normoxic rats. However, a 370\% increase in REDD1 was noted in hypophagic rats compared to ad libitum fed normoxic rats [43]. Sea level studies indicate acute caloric restriction (less than three weeks) activates AMP-activated protein kinase (AMPK $\alpha$ ), an inhibitor of mTOR [53]. Conversely, in a study evaluating 
the effects of 10 days of $20 \%$ energy deficit with $1.5 \mathrm{~g}$ protein/ $\mathrm{kg} / \mathrm{day}$, AMPK $\alpha$ was not altered [54]. However, reduced phosphorylation of intracellular signaling proteins Akt and eukaryotic initiation factor 4E binding protein 1 (4E-BP1) resulted in a 19\% decrease in MPS with energy deficit compared to weight maintenance [54]. In the absence of sufficient energy, whole body proteolysis is also increased as amino acids are mobilized and oxidized for energy or gluconeogenesis. Although the mechanism(s) remain to be fully elucidated, Carbone et al. [55] demonstrated that 21 days of $40 \%$ caloric restriction upregulated gene expression of the UP system active in muscle proteolysis. In summary, acute caloric restriction results in decreased protein synthesis and increased proteolysis. It is unknown, but likely, that caloric restriction associated with high altitude exposure elicits a similar response in protein turnover.

As a consequence of low energy intake, protein intake is also compromised with high altitude exposure. Protein intake, particularly the branched-chain amino acids (BCAA), is critical for the regulation of MPS [56]. Several sea level studies have examined the effects of varying protein prescriptions on retention of FFM during energy deficits induced by hypocaloric diets and exercise. In a study of twenty resistance trained men, $2.3 \mathrm{~g}$ protein $/ \mathrm{kg} /$ day was superior $(20 \%$ greater) than $0.9 \mathrm{~g} / \mathrm{kg}$ for retention of FFM following a $40 \%$ caloric restriction for two weeks [32]. Pasiakos et al. [31] found no benefit of protein in excess of twice the Recommended Dietary Allowance (RDA) $(1.6 \mathrm{~g}$ protein $/ \mathrm{kg})$ when comparing the RDA $(0.8 \mathrm{~g} / \mathrm{kg}), 2 \times \mathrm{RDA}(1.6 \mathrm{~g} / \mathrm{kg})$, and $3 \times \mathrm{RDA}(2.4 \mathrm{~g} / \mathrm{kg})$ on FFM retention following $40 \%$ caloric restriction for 21 days. Using an exercise-induced energy deficit of $1000 \mathrm{kcal} /$ day for seven days, Pikosky et al. [33] similarly found that $1.8 \mathrm{~g}$ protein $/ \mathrm{kg}$ was superior to $0.9 \mathrm{~g} / \mathrm{kg}$ for maintenance of nitrogen balance. This is in accordance with a meta-analysis that found protein intakes of $1.05-1.20 \mathrm{~g} / \mathrm{kg}$ associated with a $0.78 \mathrm{~kg}$ additional FFM retention and amounts $>1.2 \mathrm{~g} / \mathrm{kg}$ associated with $0.96 \mathrm{~kg}$ additional FFM retention during caloric restriction [30].

Regarding high altitude protein supplementation studies, data is limited. In rats supplemented with 10,20 or $40 \mathrm{~g}$ of protein for 26 days at $6000 \mathrm{~m}$, protein supplementation did not prevent the decrease in muscle growth [46]. In ski mountaineers supplemented with $1.5 \mathrm{~g}$ or $2.5 \mathrm{~g}$ casein protein/day for seven days at 2500-3800 m, body mass did not change. However, 50\% maximal voluntary contraction endurance of the quadriceps muscle post-skiing was decreased with the high protein dose [57]. In summary, under normoxic conditions when in energy balance, evidence suggests increasing protein intake has no further advantage on increasing FFM. However, during caloric restriction, increasing protein intake to approximately twice the RDA $(1.6 \mathrm{~g} / \mathrm{kg})$ improves nitrogen balance. Whether this level of protein intake is possible to achieve or even beneficial during prolonged high altitude exposure under hypocaloric conditions is undetermined.

\section{Nutritional Strategies for Retention of FFM at Altitude}

Targeting two primary areas of nutrition may be useful to improve FFM retention at altitude: caloric intake and protein intake. Of these two areas, only the latter would seem practical and feasible. As demonstrated in previous studies, weight maintenance is extremely difficult at progressively higher altitudes above $5000 \mathrm{~m}$. Butterfield et al. [17] was able to mitigate weight loss in four of seven subjects at $4300 \mathrm{~m}$ by providing food matched precisely to energy expenditure. Kayser et al. [18] was able to minimize weight loss at $5050 \mathrm{~m}$ by limiting exercise to minimal tasks and providing palatable 
food in a comfortable environment. However, field studies at higher elevations were unable to replicate these findings. Macdonald et al. [58] found that neither additional calories $(+11.2 \pm 4.5 \mathrm{kcal} / \mathrm{kg} /$ day body weight $)$ nor higher initial body fat mass attenuated loss of FFM during a 21-day Himalayan trek. Reynolds et al. [6] provided highly palatable food to Everest base camp personnel and climbers. Despite palatable foods, food intake decreased dramatically and weight (and FFM) loss occurred. There have been anecdotal accounts and author observations of weight maintenance in climbers who force themselves to continually eat, but for most this is extremely difficult. Therefore, increasing caloric intake may not be the most useful strategy for retention of FFM at altitude. However, manipulating protein intake, more specifically type and amount of protein, may prove a more practical strategy.

\subsection{Protein and FFM Retention}

Given the present body of research, increasing protein intake at altitude would appear a logical choice to aid retention of FFM. However, there are many limitations to this approach. At altitude increasing protein intake may not be feasible or practical. In a recent trek to Everest base camp, trekkers supplemented with protein were able to maintain a protein intake of only $1.1 \mathrm{~g}$ protein $/ \mathrm{kg} /$ day [37] which is below the $1.6 \mathrm{~g}$ protein/ $\mathrm{kg} /$ day needed to support FFM retention during negative energy balance [31]. Further, protein is thermogenic with an energy cost of approximately $20 \%-30 \%$ [59]. In an environment where oxygen is limited, increasing protein intake may be too "energetically expensive". In addition, at extreme altitudes it is unknown just how much protein can be tolerated. Early reports proposed malabsorption as an issue at extreme altitude [38]. Although largely disproven $[3,60]$, there may be some individuality regarding the amount of protein that can be ingested during extreme altitude expeditions. Lastly, perhaps the most problematic issue with protein is its satiating effect [61]. Increased satiety is considered a favorable consequence of high protein intake for sea level weight loss (dieting). However, adding more protein could potentiate the problem of blunted appetite at altitude [62] and further deplete glycogen levels and impair performance, particularly if protein consumption reduces carbohydrate intake [46,57]. Currently, no research has been conducted evaluating the effects of protein supplementation on satiety at altitude. Therefore, the best approach may be to stimulate MPS and/or decrease proteolysis with a low volume protein supplement high in MPS-promoting branched-chain amino acids and, in particular, leucine. It is worthy to note that leucine metabolites such as $\beta$-hydroxy- $\beta$-methylbutyrate (HMB) may also promote muscle anabolism, but to a lesser extent than leucine and via different or additional mechanisms to leucine [63]. Although potentially beneficial, there is currently no data evaluating the effects of HMB on muscle wasting at altitude. Therefore, the remaining discussion will focus on the direct cell signaling nutrient leucine and its role in MPS.

\subsection{Leucine and FFM Retention}

Leucine is a branched-chain amino acid that is not only a substrate for the synthesis of new proteins but is critical in mTOR cell signaling and muscle protein synthesis regulation [64-66]. Leucine may also help regulate proteolysis through downregulation of the UP pathway [67] and thereby has been marketed as both an anabolic and anticatabolic nutrient. Recent investigations have demonstrated that 
leucine in dietary protein is the main determinant of postprandial MPS [68] with liquid sources being superior to solid sources in inducing peak leucine levels [69]. Previously, leucine has been manipulated to increase muscle mass in athletes and FFM retention during hypocaloric diets at sea level (see reviews by [70,71]). More recently, due to its regulatory function on skeletal muscle, leucine has been manipulated to improve FFM retention in muscle wasting conditions associated with cancer [72] and aging [56].

The above information presents the possibility of a unique application of leucine to muscle wasting at altitude. Metabolite profiling in yeast cells has shown dramatically low levels of cellular leucine secondary to downregulation of amino acid permeases (leucine transporters) under hypoxic conditions [73]. Further, certain conditions such as endurance exercise and depleted glycogen, both conditions associated with high altitude exposure, increase leucine oxidation [74]. Observations such as these suggest that the hypoxia of altitude may exert similar effects upon leucine transport and oxidation, resulting in a "drain" on leucine availability to participate in protein synthesis. Unfortunately, palatability of amino acids, and in particular, leucine is low. However, if palatability can be achieved, providing supplemental leucine may be a feasible way of retaining FFM without the need to ingest large amounts of protein.

Under normoxic situations where high quality meal protein and energy intakes are sufficient, supplemental leucine would not be expected to exert a stimulatory effect upon protein synthesis. Glynn et al. [75] demonstrated that $10 \mathrm{~g}$ of an essential amino acid (EAA) mixture typical of a high quality protein (18\% leucine) compared to $10 \mathrm{~g}$ of EAA mixture enriched with leucine (35\% leucine) elicited similar responses in 1-h postprandial MPS despite improved mTOR signaling with higher leucine content. Similarly, in another study $16.6 \mathrm{~g}$ whey protein enriched with $3.4 \mathrm{~g}$ leucine produced a MPS response equivalent to $20 \mathrm{~g}$ whey following resistance exercise [76]. It is when high quality protein intake is insufficient, as commonly experienced with high altitude exposure, that leucine most likely may play a key role in stimulating MPS and FFM retention.

The majority of research supports the amount of 20-25 g of high quality protein ingested at one time as the maximal dose for subsequent MPS stimulation. In situations where it is not possible to ingest sufficient protein (i.e., altitude), or when the muscle is resistant to stimuli (i.e., aging), small amounts of protein enriched with leucine may enhance the MPS feeding response. In a study investigating the effects of $25 \mathrm{~g}$ whey protein ( $3 \mathrm{~g}$ leucine) compared to $6.25 \mathrm{~g}$ whey protein enriched with a leucine content equivalent to $25 \mathrm{~g}$ of whey $(0.75 \mathrm{~g}$ leucine $+2.25 \mathrm{~g}$ leucine $)$ and $6.25 \mathrm{~g}$ whey protein (0.75 g leucine), both whey and low dose whey + leucine increased MPS similarly 1-3 $\mathrm{h}$ post-feeding. However, the higher dose whey protein was more effective at sustaining increased MPS following resistance-exercise [77]. It is important to note that these results were shown in young, active males. In aging populations, higher protein (i.e., higher leucine) (40 g whey) was found to induce the greatest stimulus in MPS following resistance exercise [78]. Given the similarity between the aging and hypoxia model on blunted post-exercise MPS, leucine may provide the stimulus needed for FFM retention when protein intake is insufficient.

Sea level studies suggest leucine may also be of benefit when ingested during exercise. Although studies have investigated the effects of leucine ingested post-exercise, few have examined the effects of leucine during exercise. Pasiakos et al. [79] demonstrated that $10 \mathrm{~g}$ EAA (3.5 g leucine) ingested during 60 min of steady state $\left(60 \% \mathrm{VO}_{2 \text { peak }}\right)$ endurance exercise increased MPS by $33 \%$ compared 
with $10 \mathrm{~g}$ EAA (1.87 g leucine) although both increased Akt and mTOR phosphorylation 30 min post-exercise. Coffey et al. [80] reported similar findings examining the effects of leucine on high intensity exercise. In this study, subjects ingested $24 \mathrm{~g}$ whey protein, $4.8 \mathrm{~g}$ leucine and $50 \mathrm{~g}$ maltodextrin prior to two sprint cycling sessions. Myofibrillar protein synthesis was $48 \%$ greater than the noncaloric placebo $15 \mathrm{~min}$ post-exercise with an associated increase in Akt and mTOR phosphorylation. Although the study design of a noncaloric control limits the applicability of leucine, it does support the benefit of consuming small amounts of protein with leucine and carbohydrate during high intensity exercise that may be experienced at high altitudes.

Three studies have examined the effects of branched chain amino acids (BCAA) and leucine on body composition at altitude. Bigard et al. [81] examined the effects of BCAA (7.8 g leucine, $3.4 \mathrm{~g}$ isoleucine, $11.2 \mathrm{~g}$ valine; $1.44 \mathrm{~g}$ protein $/ \mathrm{kg}$ ) compared to carbohydrate supplementation on body composition following six days of ski mountaineering at 2500-3800 m. Body composition and muscular performance were unaffected by BCAA. However, significant weight loss only occurred in the carbohydrate supplemented group $(-1.55 \mathrm{~kg} v s$. $-0.8 \mathrm{~kg})$. In addition, Schena et al. [82] investigated the effects of BCAA (5.76 g leucine, $2.88 \mathrm{~g}$ isoleucine, $2.88 \mathrm{~g}$ valine) on body composition during a 21-day trek at a mean altitude of $3255 \mathrm{~m}$. An increase in lean muscle mass $(+1.5 \%)$ was noted in the supplemented group with no change in the control group. Because the placebo was noncaloric it is difficult to determine if the positive effects on body composition were due to BCAA or simply from increased energy intake and/or protein. More recently, in double blind randomized fashion supplemental leucine (14 g protein; $7 \mathrm{~g}$ leucine) or an isocaloric, isonitrogenous control (11 g protein; 0.34 leucine) was administered twice daily in a hot chocolate beverage during a 13 day trek to Everest base camp. All subjects lost significant body weight. However, FFM comprised $66 \%$ of the control weight loss compared with $42 \%$ of the leucine weight loss [37]. The altitude attained and duration of altitude exposure limited the extent of weight and FFM loss, but the study did demonstrate that leucine was palatable and well-tolerated up to approximately $5300 \mathrm{~m}$. Further, it is of particular importance that there was no difference in carefully documented caloric intake between leucine supplemented and nonsupplemented subjects suggesting leucine did not potentiate the increased satiety induced by altitude. More research is needed to determine if leucine is an effective strategy for FFM retention at altitude.

\section{Conclusions}

Chronic high altitude exposure is associated with significant weight loss primarily comprised of FFM. Loss of FFM has negative consequences related to decreased physical performance and increased risk of illness and injury. Studies have demonstrated at lower elevations that when subjects are provided with sufficient food and perform limited activity, energy balance can be maintained. As altitude progresses, weight maintenance becomes virtually impossible. Hypoxia, negative energy balance, and insufficient high quality protein limit the body's ability to synthesize protein secondary to inhibition of the mTOR pathway and perhaps accelerated proteolysis via upregulation of the UP system. Although this could be viewed as a favorable adaptation in the context of survivability, it is not in terms of performance and health. Increasing caloric and protein intake is difficult at high altitude due to feasibility and perturbations in appetite regulation. Therefore, the most practical strategy to 
improve FFM retention at altitude may be in the form of supplemental leucine. Clearly more research is needed in this area to determine the exact mechanisms related to altitude-induced muscle wasting, protein requirements and effectiveness of leucine for the retention of FFM during both acute and long-term high altitude exposure.

\section{Acknowledgments}

The author acknowledges E. Wayne Askew and Micah J. Drummond for their critical review and editorial assistance with this manuscript.

\section{Conflicts of Interest}

The author declares no conflict of interest.

\section{References}

1. Rose, M.S.; Houston, C.S.; Fulco, C.S.; Coates, G.; Sutton, J.R.; Cymerman, A. Operation Everest. II: Nutrition and body composition. J. Appl. Physiol. 1988, 65, 2545-2551.

2. Westerterp, K.R.; Kayser, B.; Brouns, F.; Herry, J.P.; Saris, W.H. Energy expenditure climbing Mt. Everest. J. Appl. Physiol. 1992, 73, 1815-1819.

3. Westerterp, K.R.; Kayser, B.; Wouters, L.; Le Trong, J.L.; Richalet, J.P. Energy balance at high altitude of 6542 m. J. Appl. Physiol. 1994, 77, 862-866.

4. Westerterp, K.R.; Meijer, E.P.; Rubbens, M.; Robach, P.; Richalet, J.P. Operation Everest III: Energy and water balance. Pflug. Arch. 2000, 439, 483-488.

5. Reynolds, R.D.; Lickteig, J.A.; Deuster, P.A.; Howard, M.P.; Conway, J.M.; Pietersma, A.; de Stoppelaar, J.; Deurenberg, P. Energy metabolism increases and regional body fat decreases while regional muscle mass is spared in humans climbing Mt. Everest. J. Nutr. 1999, 129, 1307-1314.

6. Reynolds, R.D.; Lickteig, J.A.; Howard, M.P.; Deuster, P.A. Intakes of high fat and high carbohydrate foods by humans increased with exposure to increasing altitude during an expedition to Mt. Everest. J. Nutr. 1998, 128, 50-55.

7. Tanner, D.A.; Stager, J.M. Partitioned weight loss and body composition changes during a mountaineering expedition: A field study. Wilderness Environ. Med. 1998, 9, 143-152.

8. Armellini, F.; Zamboni, M.; Robbi, R.; Todesco, T.; Bissoli, L.; Mino, A.; Angelini, G.; Micciolo, R.; Bosello, O. The effects of high altitude trekking on body composition and resting metabolic rate. Horm. Metab. Res. 1997, 29, 458-461.

9. Pulfrey, S.M.; Jones, P.J. Energy expenditure and requirement while climbing above $6000 \mathrm{~m}$. J. Appl. Physiol. 1996, 81, 1306-1311.

10. Hoppeler, H.; Kleinert, E.; Schlegel, C.; Claassen, H.; Howald, H.; Kayar, S.R.; Cerretelli, P. Morphological adaptations of human skeletal muscle to chronic hypoxia. Int. J. Sports Med. 1990, 11, S3-S9. 
11. Sergi, G.; Imoscopi, A.; Sarti, S.; Perissinotto, E.; Coin, A.; Inelmen, E.M.; Zambon, S.; Busetto, L.; Seresin, C.; Manzato, E. Changes in total body and limb composition and muscle strength after a 6-8 weeks sojourn at extreme altitude (5000-8000 m). J. Sports Med. Phys. Fit. 2010, 50, 450-455.

12. Fulco, C.S.; Rock, P.B.; Cymerman, A. Maximal and submaximal exercise performance at altitude. Aviat. Space Environ. Med. 1998, 69, 793-801.

13. Murdoch, D.R. Symptoms of infection and altitude illness among hikers in the Mount Everest region of Nepal. Aviat. Space Environ. Med. 1995, 66, 148-151.

14. Westerterp-Plantenga, M.S.; Westerterp, K.R.; Rubbens, M.; Verwegen, C.R.; Richelet, J.P.; Gardette, B. Appetite at "high altitude" [Operation Everest III (Comex-'97)]: A simulated ascent of Mount Everest. J. Appl. Physiol. 1999, 87, 391-399.

15. Hamad, N.; Travis, S.P. Weight loss at high altitude: Pathophysiology and practical implications. Eur. J. Gastroenterol. Hepatol. 2006, 18, 5-10.

16. Kayser, B. Nutrition and energetics of exercise at altitude. Theory and possible practical implications. Sports Med. 1994, 17, 309-323.

17. Butterfield, G.E.; Gates, J.; Fleming, S.; Brooks, G.A.; Sutton, J.R.; Reeves, J.T. Increased energy intake minimizes weight loss in men at high altitude. J. Appl. Physiol. 1992, 72, 1741-1748.

18. Kayser, B.; Narici, M.; Milesi, S.; Grassi, B.; Cerretelli, P. Body composition and maximum alactic anaerobic performance during a one month stay at high altitude. Int. J. Sports Med. 1993, 14, 244-247.

19. Consolazio, C.F.; Johnson, H.L.; Krzywicki, H.J.; Daws, T.A. Metabolic aspects of acute altitude exposure (4300 m) in adequately nourished humans. Am. J. Clin. Nutr. 1972, 25, 23-29.

20. Richard, N.A.; Koehle, M.S. Differences in cardio-ventilatory responses to hypobaric and normobaric hypoxia: A review. Aviat. Space Environ. Med. 2012, 83, 677-684.

21. Degache, F.; Larghi, G.; Faiss, R.; Deriaz, O.; Millet, G. Hypobaric versus normobaric hypoxia: Same effects on postural stability? High Alt. Med. Biol. 2012, 13, 40-45.

22. Faiss, R.; Pialoux, V.; Sartori, C.; Faes, C.; Deriaz, O.; Millet, G.P. Ventilation, oxidative stress, and nitric oxide in hypobaric versus normobaric hypoxia. Med. Sci. Sports Exerc. 2013, 45, 253-260.

23. Fulco, C.S.; Beidleman, B.A.; Muza, S.R. Effectiveness of preacclimatization strategies for high-altitude exposure. Exerc. Sport Sci. Rev. 2013, 41, 55-63.

24. Savourey, G.; Launay, J.C.; Besnard, Y.; Guinet, A.; Travers, S. Normo- and hypobaric hypoxia: Are there any physiological differences? Eur. J. Appl. Physiol. 2003, 89, 122-126.

25. Aeberli, I.; Erb, A.; Spliethoff, K.; Meier, D.; Gotze, O.; Fruhauf, H.; Fox, M.; Finlayson, G.S.; Gassmann, M.; Berneis, K.; et al. Disturbed eating at high altitude: Influence of food preferences, acute mountain sickness and satiation hormones. Eur. J. Nutr. 2013, 52, 625-635.

26. Snyder, E.M.; Carr, R.D.; Deacon, C.F.; Johnson, B.D. Overnight hypoxic exposure and glucagon-like peptide-1 and leptin levels in humans. Appl. Physiol. Nutr. Metab. 2008, 33, 929-935. 
27. Barnholt, K.E.; Hoffman, A.R.; Rock, P.B.; Muza, S.R.; Fulco, C.S.; Braun, B.; Holloway, L.; Mazzeo, R.S.; Cymerman, A.; Friedlander, A.L. Endocrine responses to acute and chronic high-altitude exposure $(4300 \mathrm{~m})$ : Modulating effects of caloric restriction. Am. J. Physiol. Endocrinol. Metab. 2006, 290, E1078-E1088.

28. Westerterp, K.R.; Saris, W.H.; van Es, M.; Ten Hoor, F. Use of the doubly labeled water technique in humans during heavy sustained exercise. J. Appl. Physiol. 1986, 61, 2162-2167.

29. Weinheimer, E.M.; Sands, L.P.; Campbell, W.W. A systematic review of the separate and combined effects of energy restriction and exercise on fat-free mass in middle-aged and older adults: Implications for sarcopenic obesity. Nutr. Rev. 2010, 68, 375-388.

30. Krieger, J.W.; Sitren, H.S.; Daniels, M.J.; Langkamp-Henken, B. Effects of variation in protein and carbohydrate intake on body mass and composition during energy restriction: A meta-regression 1. Am. J. Clin. Nutr. 2006, 83, 260-274.

31. Pasiakos, S.M.; Cao, J.J.; Margolis, L.M.; Sauter, E.R.; Whigham, L.D.; McClung, J.P.; Rood, J.C.; Carbone, J.W.; Combs, G.F., Jr.; Young, A.J. Effects of high-protein diets on fat-free mass and muscle protein synthesis following weight loss: A randomized controlled trial. FASEB J. 2013, 27, 3837-3847.

32. Mettler, S.; Mitchell, N.; Tipton, K.D. Increased protein intake reduces lean body mass loss during weight loss in athletes. Med. Sci. Sports Exerc. 2010, 42, 326-337.

33. Pikosky, M.A.; Smith, T.J.; Grediagin, A.; Castaneda-Sceppa, C.; Byerley, L.; Glickman, E.L.; Young, A.J. Increased protein maintains nitrogen balance during exercise-induced energy deficit. Med. Sci. Sports Exerc. 2008, 40, 505-512.

34. Fulco, C.S.; Friedlander, A.L.; Muza, S.R.; Rock, P.B.; Robinson, S.; Lammi, E.; Baker-Fulco, C.J.; Lewis, S.F.; Cymerman, A. Energy intake deficit and physical performance at altitude. Aviat. Space Environ. Med. 2002, 73, 758-765.

35. Fulco, C.S.; Hoyt, R.W.; Baker-Fulco, C.J.; Gonzalez, J.; Cymerman, A. Use of bioelectrical impedance to assess body composition changes at high altitude. J. Appl. Physiol. 1992, 72, 2181-2187.

36. Muller, W.; Horn, M.; Furhapter-Rieger, A.; Kainz, P.; Kropfl, J.M.; Maughan, R.J.; Ahammer, H. Body composition in sport: A comparison of a novel ultrasound imaging technique to measure subcutaneous fat tissue compared with skinfold measurement. Br. J. Sports Med. 2013, 47, 1028-1035.

37. Wing-Gaia, S.L.; Gershenoff, D.C.; Drummond, M.J.; Askew, E.W. Effect of leucine supplementation on fat free mass with prolonged hypoxic exposure during a 13-day trek to Everest Base Camp: A double-blind randomized study. Appl. Physiol. Nutr. Metab. 2014, 39, doi:10.1139/apnm-2013-0319.

38. Boyer, S.J.; Blume, F.D. Weight loss and changes in body composition at high altitude. J. Appl. Physiol. 1984, 57, 1580-1585.

39. Matthews, D.E. Proteins and Amino Acids. In Modern Nutrition and Health and Disease, 9th ed.; Shils, M.O.J., Shike M., Ross A., Eds.; Williams and Wilkins: Baltimore, MD, USA, 1999; pp. 11-48.

40. Welle, S.; Thornton, C.; Statt, M.; McHenry, B. Postprandial myofibrillar and whole body protein synthesis in young and old human subjects. Am. J. Physiol. 1994, 267, E599-E604. 
41. Carbone, J.W.; McClung, J.P.; Pasiakos, S.M. Skeletal muscle responses to negative energy balance: Effects of dietary protein. Adv. Nutr. 2012, 3, 119-126.

42. Brugarolas, J.; Lei, K.; Hurley, R.L.; Manning, B.D.; Reiling, J.H.; Hafen, E.; Witters, L.A.; Ellisen, L.W.; Kaelin, W.G., Jr. Regulation of mTOR function in response to hypoxia by REDD1 and the TSC1/TSC2 tumor suppressor complex. Genes Dev. 2004, 18, 2893-2904.

43. Favier, F.B.; Costes, F.; Defour, A.; Bonnefoy, R.; Lefai, E.; Bauge, S.; Peinnequin, A.; Benoit, H.; Freyssenet, D. Downregulation of Akt/mammalian target of rapamycin pathway in skeletal muscle is associated with increased REDD1 expression in response to chronic hypoxia. Am. J. Physiol. Regul. Integr. Comp. Physiol. 2010, 298, R1659-R1666.

44. Preedy, V.R.; Smith, D.M.; Sugden, P.H. The effects of 6 hours of hypoxia on protein synthesis in rat tissues in vivo and in vitro. Biochem. J. 1985, 228, 179-185.

45. Schnakenberg, D.D.; Krabill, L.F.; Weiser, P.C. The anorexic effect of high altitude on weight gain, nitrogen retention and body composition of rats. J. Nutr. 1971, 101, 787-796.

46. Bigard, A.X.; Douce, P.; Merino, D.; Lienhard, F.; Guezennec, C.Y. Changes in dietary protein intake fail to prevent decrease in muscle growth induced by severe hypoxia in rats. J. Appl. Physiol. 1996, 80, 208-215.

47. Vigano, A.; Ripamonti, M.; de Palma, S.; Capitanio, D.; Vasso, M.; Wait, R.; Lundby, C.; Cerretelli, P.; Gelfi, C. Proteins modulation in human skeletal muscle in the early phase of adaptation to hypobaric hypoxia. Proteomics 2008, 8, 4668-4679.

48. Etheridge, T.; Atherton, P.J.; Wilkinson, D.; Selby, A.; Rankin, D.; Webborn, N.; Smith, K.; Watt, P.W. Effects of hypoxia on muscle protein synthesis and anabolic signaling at rest and in response to acute resistance exercise. Am. J. Physiol. Endocrinol. Metab. 2011, 301, E697-E702.

49. Imoberdorf, R.; Garlick, P.J.; McNurlan, M.A.; Casella, G.A.; Marini, J.C.; Turgay, M.; Bartsch, P.; Ballmer, P.E. Skeletal muscle protein synthesis after active or passive ascent to high altitude. Med. Sci. Sports Exerc. 2006, 38, 1082-1087.

50. Sheffield-Moore, M.; Yeckel, C.W.; Volpi, E.; Wolf, S.E.; Morio, B.; Chinkes, D.L.; Paddon-Jones, D.; Wolfe, R.R. Postexercise protein metabolism in older and younger men following moderate-intensity aerobic exercise. Am. J. Physiol. Endocrinol. Metab. 2004, 287, E513-E522.

51. Chaudhary, P.; Suryakumar, G.; Prasad, R.; Singh, S.N.; Ali, S.; Ilavazhagan, G. Chronic hypobaric hypoxia mediated skeletal muscle atrophy: Role of ubiquitin-proteasome pathway and calpains. Mol. Cell. Biochem. 2012, 364, 101-113.

52. Holm, L.; Haslund, M.L.; Robach, P.; van Hall, G.; Calbet, J.A.; Saltin, B.; Lundby, C. Skeletal muscle myofibrillar and sarcoplasmic protein synthesis rates are affected differently by altitude-induced hypoxia in native lowlanders. PLoS One 2010, 5, e15606.

53. McIver, C.M.; Wycherley, T.P.; Clifton, P.M. MTOR signaling and ubiquitin-proteosome gene expression in the preservation of fat free mass following high protein, calorie restricted weight loss. Nutr. Metab. 2012, 9, 83.

54. Pasiakos, S.M.; Vislocky, L.M.; Carbone, J.W.; Altieri, N.; Konopelski, K.; Freake, H.C.; Anderson, J.M.; Ferrando, A.A.; Wolfe, R.R.; Rodriguez, N.R. Acute energy deprivation affects skeletal muscle protein synthesis and associated intracellular signaling proteins in physically active adults. $J$. Nutr. 2010, 140, 745-751. 
55. Carbone, J.W.; Margolis, L.M.; McClung, J.P.; Cao, J.J.; Murphy, N.E.; Sauter, E.R.; Combs, G.F., Jr.; Young, A.J.; Pasiakos, S.M. Effects of energy deficit, dietary protein, and feeding on intracellular regulators of skeletal muscle proteolysis. FASEB J. 2013, 27, 5104-5111.

56. Drummond, M.J.; Dreyer, H.C.; Fry, C.S.; Glynn, E.L.; Rasmussen, B.B. Nutritional and contractile regulation of human skeletal muscle protein synthesis and mTORC1 signaling. J. Appl. Physiol. 2009, 106, 1374-1384.

57. Bigard, A.X.; Satabin, P.; Lavier, P.; Canon, F.; Taillandier, D.; Guezennec, C.Y. Effects of protein supplementation during prolonged exercise at moderate altitude on performance and plasma amino acid pattern. Eur. J. Appl. Physiol. Occup. Physiol. 1993, 66, 5-10.

58. Macdonald, J.H.; Oliver, S.J.; Hillyer, K.; Sanders, S.; Smith, Z.; Williams, C.; Yates, D.; Ginnever, H.; Scanlon, E.; Roberts, E.; et al. Body composition at high altitude: A randomized placebo-controlled trial of dietary carbohydrate supplementation. Am. J. Clin. Nutr. 2009, 90, 1193-1202.

59. Tappy, L. Thermic effect of food and sympathetic nervous system activity in humans. Reprod. Nutr. Dev. 1996, 36, 391-397.

60. Kayser, B.; Acheson, K.; Decombaz, J.; Fern, E.; Cerretelli, P. Protein absorption and energy digestibility at high altitude. J. Appl. Physiol. 1992, 73, 2425-2431.

61. Potier, M.; Darcel, N.; Tome, D. Protein, amino acids and the control of food intake. Curr. Opin. Clin. Nutr. Metab. Care 2009, 12, 54-58.

62. Westerterp, K.R.; Kayser, B. Body mass regulation at altitude. Eur. J. Gastroenterol. Hepatol. 2006, 18, 1-3.

63. Wilkinson, D.J.; Hossain, T.; Hill, D.S.; Phillips, B.E.; Crossland, H.; Williams, J.; Loughna, P.; Churchward-Venne, T.A.; Breen, L.; Phillips, S.M.; et al. Effects of leucine and its metabolite $\beta$-hydroxy- $\beta$-methylbutyrate on human skeletal muscle protein metabolism. J. Physiol. 2013, 591, 2911-2923.

64. Fujita, S.; Dreyer, H.C.; Drummond, M.J.; Glynn, E.L.; Cadenas, J.G.; Yoshizawa, F.; Volpi, E.; Rasmussen, B.B. Nutrient signalling in the regulation of human muscle protein synthesis. J. Physiol. 2007, 582, 813-823.

65. Anthony, J.C.; Yoshizawa, F.; Anthony, T.G.; Vary, T.C.; Jefferson, L.S.; Kimball, S.R. Leucine stimulates translation initiation in skeletal muscle of postabsorptive rats via a rapamycin-sensitive pathway. J. Nutr. 2000, 130, 2413-2419.

66. Lynch, C.J.; Patson, B.J.; Anthony, J.; Vaval, A.; Jefferson, L.S.; Vary, T.C. Leucine is a direct-acting nutrient signal that regulates protein synthesis in adipose tissue. Am. J. Physiol. Endocrinol. Metab. 2002, 283, E503-E513.

67. Nakashima, K.; Ishida, A.; Yamazaki, M.; Abe, H. Leucine suppresses myofibrillar proteolysis by down-regulating ubiquitin-proteasome pathway in chick skeletal muscles. Biochem. Biophys. Res. Commun. 2005, 336, 660-666.

68. Norton, L.E.; Wilson, G.J.; Layman, D.K.; Moulton, C.J.; Garlick, P.J. Leucine content of dietary proteins is a determinant of postprandial skeletal muscle protein synthesis in adult rats. Nutr. Metab. 2012, 9, 67. 
69. Burke, L.M.; Winter, J.A.; Cameron-Smith, D.; Enslen, M.; Farnfield, M.; Decombaz, J. Effect of intake of different dietary protein sources on plasma amino acid profiles at rest and after exercise. Int. J. Sport Nutr. Exerc. Metab. 2012, 22, 452-462.

70. Jitomir, J.; Willoughby, D.S. Leucine for retention of lean mass on a hypocaloric diet. J. Med. Food 2008, 11, 606-609.

71. Balage, M.; Dardevet, D. Long-term effects of leucine supplementation on body composition. Curr. Opin. Clin. Nutr. Metab. Care 2010, 13, 265-270.

72. Peters, S.J.; van Helvoort, A.; Kegler, D.; Argiles, J.M.; Luiking, Y.C.; Laviano, A.; van Bergenhenegouwen, J.; Deutz, N.E.; Haagsman, H.P.; Gorselink, M.; et al. Dose-dependent effects of leucine supplementation on preservation of muscle mass in cancer cachectic mice. Oncol. Rep. 2011, 26, 247-254.

73. Gleason, J.E.; Corrigan, D.J.; Cox, J.E.; Reddi, A.R.; McGinnis, L.A.; Culotta, V.C. Analysis of hypoxia and hypoxia-like states through metabolite profiling. PLoS One 2011, 6, e24741.

74. Howarth, K.R.; Phillips, S.M.; MacDonald, M.J.; Richards, D.; Moreau, N.A.; Gibala, M.J. Effect of glycogen availability on human skeletal muscle protein turnover during exercise and recovery. J. Appl. Physiol. 2010, 109, 431-438.

75. Glynn, E.L.; Fry, C.S.; Drummond, M.J.; Timmerman, K.L.; Dhanani, S.; Volpi, E.; Rasmussen, B.B. Excess leucine intake enhances muscle anabolic signaling but not net protein anabolism in young men and women. J. Nutr. 2010, 140, 1970-1976.

76. Tipton, K.D.; Elliott, T.A.; Ferrando, A.A.; Aarsland, A.A.; Wolfe, R.R. Stimulation of muscle anabolism by resistance exercise and ingestion of leucine plus protein. Appl. Physiol. Nutr. Metab. 2009, 34, 151-161.

77. Churchward-Venne, T.A.; Burd, N.A.; Mitchell, C.J.; West, D.W.; Philp, A.; Marcotte, G.R.; Baker, S.K.; Baar, K.; Phillips, S.M. Supplementation of a suboptimal protein dose with leucine or essential amino acids: Effects on myofibrillar protein synthesis at rest and following resistance exercise in men. J. Physiol. 2012, 590, 2751-2765.

78. Yang, Y.; Breen, L.; Burd, N.A.; Hector, A.J.; Churchward-Venne, T.A.; Josse, A.R.; Tarnopolsky, M.A.; Phillips, S.M. Resistance exercise enhances myofibrillar protein synthesis with graded intakes of whey protein in older men. Br. J. Nutr. 2012, 108, 1780-1788.

79. Pasiakos, S.M.; McClung, H.L.; McClung, J.P.; Margolis, L.M.; Andersen, N.E.; Cloutier, G.J.; Pikosky, M.A.; Rood, J.C.; Fielding, R.A.; Young, A.J. Leucine-enriched essential amino acid supplementation during moderate steady state exercise enhances postexercise muscle protein synthesis. Am. J. Clin. Nutr. 2011, 94, 809-818.

80. Coffey, V.G.; Moore, D.R.; Burd, N.A.; Rerecich, T.; Stellingwerff, T.; Garnham, A.P.; Phillips, S.M.; Hawley, J.A. Nutrient provision increases signalling and protein synthesis in human skeletal muscle after repeated sprints. Eur. J. Appl. Physiol. 2011, 111, 1473-1483.

81. Bigard, A.X.; Lavier, P.; Ullmann, L.; Legrand, H.; Douce, P.; Guezennec, C.Y. Branched-chain amino acid supplementation during repeated prolonged skiing exercises at altitude. Int. J. Sport Nutr. 1996, 6, 295-306. 
82. Schena, F.; Guerrini, F.; Tregnaghi, P.; Kayser, B. Branched-chain amino acid supplementation during trekking at high altitude. The effects on loss of body mass, body composition, and muscle power. Eur. J. Appl. Physiol. Occup. Physiol. 1992, 65, 394-398.

(C) 2014 by the authors; licensee MDPI, Basel, Switzerland. This article is an open access article distributed under the terms and conditions of the Creative Commons Attribution license (http://creativecommons.org/licenses/by/3.0/). 